\title{
Commercialization Inabilities of Rural Value Chain Activities in Emerging Markets: The Theory of Constraints Approach
}

\author{
Nicholaus Bhikolimana Tutuba \\ Mzumbe University
}

\begin{abstract}
Why value chain activities of rural economies in emerging markets are not commercial? Carpenters in rural Tanzania have been working hard to improve their lives, but they remained poor as they cannot create value for customers and capture a sizable value from the activity. This qualitative case study uses the Theory of Constraints to detect the limiting factors for the commercialization abilities of carpenters in rural Tanzania. Access to finance and basic amenities, technology, business management skills, business attitude, and commitment are the weakest links that limit the ability of carpenters to commercialize their activities. Enhancing technology adoption, building business attitude, culture and skills for rural carpenters is important to commercialize carpentry activities in emerging markets. Linking the Theory of Constraints and the Value Chain theory in management sciences sets an empirical suggestion to commercialize rural economies in emerging markets. Commercialization of rural value chain activities can be done by changing the firms' abilities to create value to potential customers and capture value from the activity.
\end{abstract}

Keywords: forest value chain, value creation, value capture, theory of constraints

\section{INTRODUCTION}

In developing areas, rural and urban local markets have unique characteristics that include size, growth rate, competition, and opportunity for innovation (Majumder, 2012; Chikweche, 2013; Jun et al., 2013). This presents an excellent opportunity for business growth for rural and urban businesses: Commercialization abilities of the value chain of rural economies. Surprisingly, most value chains of rural markets like carpentry (Msamula et al., 2016), beekeeping (Tutuba \& Vanhaverbeke, 2018), and agriculture (Kyaruzi \& Ngowi, 2011) are still under-served or yet to be explored. They are served by a sector that is poorly organized, functions through disorganized channels, with uncoordinated actors. Commercialization practices are still inefficient, weak, and disorganized.

Tanzania is endowed with immense forest resources which are indispensable for sustainable rural development as they can promote diverse rural value chain activities (Tutuba \& Vanhaverbeke, 2018; Tutuba et al., 2019a). But, the experience is different, "forest resources do not at present provide a sufficient contribution to the Tanzanian economy. A mismatch exists between the abundance of forest resources and the socioeconomic gains from such resources" (Msamula et al., 2018, p.188). For example, forests serve as a potential source of raw materials like logs and timbers for carpenters in the wood furniture industry. But, rural carpenters remain poor, do not show significant economic and social development: They have not been able to commercialize the activity by creating value to customers and capture a sizable value from 
the activity. Therefore, it is important to investigate the commercialization inabilities of rural value chain activities in emerging markets.

To commercialize their activities, firms are required to create value for their target customers, deliver value and capture a sizable value from the activity (Sanchez \& Ricart, 2010; Zott \& Amit, 2014; Peprah et al., 2021) because customers tend to buy products that have [more] value (Osterwalder \& Pigneur, 2010; Tutuba \& Msamula, 2020). Similarly, the competitive performances of firms depending on their abilities to create additional value for consumers (Msamula et al., 2016). Therefore, the inability of rural carpenters to gain economic advantage and competitive advantage tells us that they are unable to create value, deliver value to customers and capture value from customers. This raises some questions: why carpenters in the carpentry [woodworking] sector in Tanzania not creating value for customers? Why are they not capturing a sizable value from the activity? What are the factors constraining their value-creating and value capturing abilities? What can be done to promote the value creation and value capture abilities of carpenters in the industry? The study uses the Theory of Constraints (TOC) to analyze the limiting factors to commercialize carpentry activities in Tanzania. The study contributes to a theoretical understanding and application of the TOC, value chain and value theory. Also, it builds on the body of literature on the factors constraining commercialization abilities in the woodworking sector in emerging economies like Tanzania.

This study is organized as follows: following this introduction, first, we provide the theoretical review and conceptualize key concepts of the study. Then we present the methods and approach followed by the findings. Finally, we discuss the findings and provide the main conclusions and implications.

\section{THEORETICAL REVIEW}

This section review some work of kinds of literature and theories of the key concepts of the study.

\section{The Value Chain Theory}

The value chain concept emerged and comes through business management after the seminal work of Porter (1985). The term value chain represents a series of activities that provide value to customers in the form of a product (Walsh, 2011; Jaligot et al., 2016). It is the full range of activities that are required to bring a product from conception, through the different phases of product delivery to final consumers, and final disposal after use (Kaplinsky \& Morris, 2001; Tutuba \& Msamula, 2020). It is a strategic network between independent business organizations i.e. linking different firms within a supply chain operating to deliver value to target customers (Collins et al., 2015; Tutuba \& Msamula, 2020). Furthermore, Porter (1985) presented the value chain analysis as a model for the identification and measurement of those activities comprising a firm's value chain. He argues that "gaining and sustaining competitive advantage depends on understanding not only a firm's value chain but how the firm fits in the overall value system" (p. 34). Carpenters can commercialize their activities if they can gain a competitive advantage by considering their value chain in the creation system.

In the value system, every single firm occupies a particular position within the value chain structure and adds value to the 'inputs' before passing them to the next actor (Jaligot et al, 2016; Msamula et al., 2018). What is important here is not only the position that the firm hold in the value chain but also the capabilities (Teece, 2018; Tidd \& Bessant, 2018) to carry out activities to add value: The firm has to perform some activities to add value before passing it to the next actor (Tutuba et al., 2019b). In this regard, value creation is not just adding value step after step but the configuration of the roles - redefining the valueadding activities - and relationships among actors of the value-creating system. Therefore, the value chain creates value by a value system or value-creating system and not a single firm. For example, carpenters cannot create value alone, they have to strategically link with other actors like timber makers in the furniture industry so that they can create and deliver value to customers. It is with this understanding that we define value chain as the ability of firms to co-create value through the strategic interlinkage, and performance of a series of activities from the acquisition of the raw materials to consumption and disposal.

Moreover, the position that a firm occupies in the value-creating system can play a role in creating value than other firms as a result of 'position advantage' (Tidd and Bessant, 2018). The position advantage 
can be due to the size or power of the firm, complementary assets, brands and standards, and access to raw materials, distribution channel, and customers. As a result, a value chain represents a set of activities that different firm operating in a specific industry performs to deliver the product for the market: different links connects or work together to deliver value to customers. Each link in the value chain involves a source input, a process of value addition and selling the material to the next link in the chain: each step adds value to the product and often generates more revenue than the previous step (Jaligot et al., 2016; Collins et al., 2015). The commercialization abilities or the benefits to the firm comes in the form of profits when customers are willing to pay for that value an amount above the costs associated with creating that value. Therefore, while rural entrepreneurship is essential to stimulate rural economies and foster inclusive growth, carpenters have not fulfilled expectations in rural emerging economies: They remained poor as they are unable to create value for their customers and capture a sizable value.

\section{The Value Theory}

Value creation is a widely used concept in strategic management. Porter (1985) argue that the value chain consists of several activities in a business that are involved in creating and making products available to the market. In Porter's view: value is the amount buyers are willing to pay for what a firm provides them. But, Osterwalder and Pigneur (2010) argue that value proposition has two faces; whom the value is created for (i.e., the customer or value consumer) and who creates value (i.e., the firm or value creator). Indicators of customer value include customization, design, brand, price, cost reduction, risk reduction, accessibility and convenience. For commercialization purposes of rural value chains, this view of value is the most suitable description of value in the furniture industry. Therefore, this study adopts the description of value as many of the lies within the product feature of furniture.

Furthermore, within the value creation theory, firms like carpenters have to consider some factors which affect value creation and hence the commercialization abilities of a firm. Some of the factors include strategies and market orientation; human resources in terms of education, experience and resilience of entrepreneurs (Isaga et al., 2015; Msamula et al., 2016); investment in research and development, technological resources, financial resources (Tutuba \& Vanhaverbeke, 2018); location of the business, capabilities (Teece, 2018; Tidd \& Bessant, 2018); physical distance between upstream and downstream actors and social capital which includes membership in business associations (Isaga, 2018). Furthermore, Msamula et al., (2016) argue that business relationships between a firm and stakeholders such as suppliers, and customers; knowledge and research centres; technology centres; and consultants are of importance as such relationships are linked to the value creation abilities of a business. The intensity of competition, the extent of imports to developing countries (Isaga et al., 2015), and the interaction of actors through governance structures (Tutuba \& Msamula, 2020) are all additional factors that affect the distribution of benefits across the rural economy. However, these factors exist within the industries as well as within the supply chains in which commercial enterprises operate. The TOC argue that a system cannot be constrained by so many links but only a few. So, the commercialization of carpentry activities cannot be limited by so many factors. The study uses the cause-and-effect approach of the TOC to narrow down the "symptoms" to reach the real constraining factors of value creation and hence value capture.

\section{Theory of Constraints}

The TOC has been commonly known as a management approach that aims to manage breakthrough improvements by focusing on a constraint that prevents a system from achieving a higher level of performance (Simatupang et al., 2004). Dettmer (1997) argue that TOC views a system [carpentry] as a chain composed of many links which are strongly interdependent and all contribute to the system goal. Therefore, if the system fails to achieve its goal, the main reason will be the underperformance of at least one of the links, also called the weakest links (Goldratt \& Cox, 2004; Moynihan, 2014) or a constraint (Tutuba \& Vanhaverbeke, 2018). This is to say that, the overall performance of carpenters is restricted by its weakest link because the chain is only as strong as its weakest link. To improve the performance of a system, the first step must be to identify [a constraint] the system's weakest link. 
Identifying a constraint in a system has been a challenge to most managers because they focus on visible negative effects, rather than the root cause of the problem. However, based on the underlying foundation of the TOC, managers can identify the root cause of negative effects. TOC focuses on the cause-and-effect thinking process to identify the constraints (Dettmer, 2000). To improve the performance of the system, the rest of the system links will then be restructured around the identified constraint. The cause-and-effect thinking processes of TOC has been applied to identify, understand, and improve all systems in an organization (Goldratt \& Cox, 2004). The process uses three questions (Rahma, 2002): what to change; what to change into, and how to cause the change? However, this study aims to identify constraints that limit the ability of carpenters to commercialize their activities in the woodwork systems. Therefore, the study is limited to the first question: what to change?

What to change? This is the first question, and the first step of the TOC, and aims to define the core problems found in a system. Junior et al., (2004) argue that this step is constructed from a cross-functional logic that analyses the core problems of a system in depth. By using the TOC approach, the what to change question is answered by the construction of a current reality tree (CRT) from a list of observable symptoms. CRT is a logical structure of thinking tools that depict the reality in a given system (Rahma, 2002; Junior et al., 2004). CRT aims to define the core problems found in a specific system. To do this, a scientific method based on cause-and-effect is used to identify the underlying common cause, and the core problems for all of the symptoms (Dettmer, 2000). Since this study is limited to what to change the question, the cause-and-effect technique will be used to identify the weakest link for commercialization inabilities of carpenters in the woodwork industry in Tanzania.

\section{APPROACH AND METHODOLOGY}

This qualitative study descriptive approach (Hair, 2007; Saunders et al., 2009) employs a multiple-case research design using a holistic approach (Yin, 2014, 2018). By using the saturation criteria 18 cases from Kigoma (4), Tabora (8), and Iringa (6) regions were purposively selected. Their external conditions differ and therefore their diverging results can be attributed to such conditions. The level of availability and accessibility of basic amenities in rural areas and their descriptive nature is the condition for the inclusion of cases in this study. Data were triangularly collected through interviews and observations. This technique allows the collection of more information to provide a holistic view of the studied phenomenon (Elliott \& Timulak, 2005; Hair, 2007). Also, the methods make collected data stronger as Yin (2014, p.10) suggested, "you always will be better off by using multiple rather than single sources of evidence".

After transcribing the interviews and developing field notes, data coding was conducted. The attribute coding method is used to capture descriptive features of rural carpentry such as size, age, productivity, and formalization status; it is a suitable coding method in capturing descriptive features of the study cases (Saldana, 2013; Msamula et al., 2016). The cause-and-effect analysis of the CTR follows. It uses derived themes from the codes; with such the TOC suggest that the factors termed as the weakest links be linked to finding the root cause for commercialization inabilities of rural carpenters in Tanzania. With the research methodology outlined, the next section presents the research findings.

\section{FINDINGS}

This section presents the findings of the research by presenting descriptive characteristics of carpenters in the wood furniture industry. Followed by the explanations for the commercialization inability of carpenters in the rural areas of Tanzania.

\section{Description of Rural Carpenters}

Carpenters in rural areas have different features and characteristics to include: size, age, ownership or management, formalization, and capital investment describes rural carpentry firms. Table 1 below summarizes these findings. 
TABLE 1

CHARACTERISTICS OF RURAL CARPENTERS IN TANZANIA

\begin{tabular}{|c|c|c|c|}
\hline MSEs Characteristic & \multicolumn{3}{|l|}{ Findings on the characteristic } \\
\hline Size of MSEs & $\begin{array}{l}\text { Less than } 5 \text { workforces } \\
13 \text { firms }(72.2 \%)\end{array}$ & \multicolumn{2}{|l|}{$\begin{array}{l}5-49 \text { workforces } \\
5 \text { Firms }(27.8 \%)\end{array}$} \\
\hline Formalization & $\begin{array}{l}\text { Formal firms } \\
3 \text { firms }(16.7 \%)\end{array}$ & \multicolumn{2}{|c|}{$\begin{array}{l}\text { Informal or unregistered firms } \\
15 \text { firms }(83.3 \%)\end{array}$} \\
\hline Management & $\begin{array}{l}\text { Sole firms } \\
16 \text { firms }(88.9 \%)\end{array}$ & \multicolumn{2}{|c|}{$\begin{array}{l}\text { Limited companies } \\
2 \text { firms }(11.1 \%)\end{array}$} \\
\hline Age of MSEs & $\begin{array}{l}\text { Less than } 5 \text { years } \\
10 \text { firms }(55.6 \%)\end{array}$ & $\begin{array}{l}5-10 \text { years } \\
7 \text { firms }(38.9 \%)\end{array}$ & $\begin{array}{l}10+\text { years } \\
1 \text { firm }(5.5 \%)\end{array}$ \\
\hline Capital investment & $\begin{array}{l}\text { Less than } 5 \text { million (Tshs) } \\
14 \text { firms }(77.8 \%)\end{array}$ & \multicolumn{2}{|c|}{$\begin{array}{l}\text { 5-200 million Tshs } \\
4 \text { firms }(22.2 \%)\end{array}$} \\
\hline
\end{tabular}

Source: Research Findings (2021).

\section{Value Creation}

Rural carpenters create value from the forest resources by making different products including domestic furniture like beds, cupboards, and sitting room sofas; office furniture like office tables and chairs, school desks and bookshelves; and construction or building furniture like doors, windows, and roofing of houses. We observed that the most frequently manufactured products are beds and doors.

Carpenters from rural areas have three perceived elements of value creation that are necessary to commercialize their products: (1) the quality of inputs that are used to make a piece of particular furniture, (2) the quality of the product's features, and (3) the quality of delivery services. The quality of raw materials is described in terms of the types and quality of timber used to make a piece of furniture. The former is measured in terms of hardwoods, softwoods, woods from natural trees, and woods from planted trees while the latter is measures in terms of dryness and durability. Similarly, durable timbers are the ones coming from trees as opposed to non-timber materials such as chipboards and fiberboards.

Moreover, carpenters measure the quality of products' features in terms of designs and styles: Shaping, smoothing, vanishing, coloring and decorating the furniture. Firms with the ability to smoothen the furniture, polish well the product and decorating with shapes, corners, and cuttings create more value and hence commercialization abilities. Regarding the quality of the delivery services, the study indicates that reliability in terms of timely delivery of products to the customer is the most important factor. Other factors include trust and delivering the product in the same design and feature as agreed or displayed before receiving an order. Customers prefer to buy ready-made furniture because most carpenters are not reliable, cannot be trusted, and in some cases, they deliver products not in the same design as proposed or agreed with customers.

\section{The Commercialization Constraints}

To understand the reasons for value creation inability and hence commercialization inabilities, the theory of constraints suggests understanding the root causes of the lack of value creation by rural carpenters in the wood furniture industry. This study indicates that the reasons for value creation inability include: limited technology, financial capital, raw materials, and skills and competencies. Other factors are intangible resources, improper planning, and insufficient commitments of rural carpenters in furniture manufacturing businesses.

\section{Competition and Legal Issues}

It is found that the competition and legal concerns cause the inability of the firms to create value. Carpentry firms face all forms of competition: Price competition, competition within the local area, competition within the carpentry association, and competition with imported products: 
"...competition is very high in our area, we are competing against each other. For example, the normal price for a standard bed is Tshs. 150,000. But you may find some carpenters who sell it for Tshs. 120,000 for the same bed manufactures using the same raw materials and the same design".

\section{Access to Markets}

The lack of access to potential markets is the principal reason for value creation and value capture inabilities of firms from rural with limited access to transport. Carpenters from these areas serve customers who are in the localities. But these customers have high bargaining power as they have potential information on costs, availability of raw materials and competitors prices and services:

\section{Commitment and Business Attitude}

Agriculture is the major economic activity of most rural people, carpenters are no exception. Rural carpenters depend much on other income-generating activities outside furniture: Making furniture is not their main income-generating activity. With their involvement in other income-generating activities, they become less committed to furniture making. This lack of commitment limits their ability to confront the challenges which undermine their commercialization abilities. They lack creativity and innovation in creating value and delivering value to customers. Although the product's market exists, and raw materials are available, the attitude towards carpentry business and their commitment limits their productivity, creativity and innovation, and hence commercialization abilities.

\section{Trust Between Carpenters and Customers}

The main cause of value creation inability rests in customers' distrust of a particular carpenter for the firm. Consumer trust is undermined because carpenters are not delivering the products to their customers as promised. The owner of one carpentry firm put it thus:

".... we, carpenters, are not trustworthy. We are losing customers because of trust. When we tell the customer that the furniture will be ready in three days, then we should deliver the furniture within time. This is important because it is the trust our customers have in us that matters. But, most customers opt for ready-made furniture because they have been turned down by some of the carpenters"

\section{Limited Technology,}

Making quality furniture requires good working tools and equipment. Also, to be productive, a carpenter should have efficient machines and working tools. Limited access to adequate technologies like modern furniture-making machines affects productivity and the ability to make quality furniture. The owner of one of the firms said:

"... making a large number of furniture in a short period is difficult because we mostly use hand tools. Also, making designer furniture with good finishing requires good machines and tools which we do not have"

\section{Limited Technical and Business Management Skills}

Most carpenters in the wood furniture industry have limited technical and business management skills. Regarding the former skills, carpenters are limited with the use of carpentry machines and tools like jigsaw, wood spray, and smoothing tools. Regarding the business management skills, carpenters are limited with the ability to formalize business, record-keeping, customer service, channel management and innovation. For example, the use of middlemen to sell their products to urban customers limit customer knowledge, understanding of customer needs, and hence limit their commercialization abilities. Similarly, the lack of business management skills limits their ability to reach profitable markets in urban areas. The owner of one of the firms pointed out that: 


\section{Limited Access to Important Amenities}

Access to important amenities like electricity, communication services like the mobile phone network, and reliable transport services limits the ability of rural carpenters to create value, deliver value and capture value. The potential market for such carpenters is the local customers: They sell their products to the customers who are only available in the local areas. A very limited market is available for their products. Most rural customers are farmers who have money to buy furniture after harvesting seasons. So, the peak season for furniture firms is the harvest season which is mostly three months in a year. Make-to-order is the dominant production strategy that requires customers to make advance payments for the ordered products. Such arrangements of advance payments cause consumer inconvenience and increase competition as customers will go for imported furniture or to other carpenters who have ready-made furniture.

The findings show that different groups of cases have different reasons for the inability of rural carpentry firms in the wood furniture industry to commercialize their activities. These reasons are both internal and external to the rural carpentry firm. However, the Theory of Constraints argues that the weakest links of the system are very few. And if the demand exceeds supply, the link should be from internal. In this regard, the commercialization inabilities cannot be caused by so many factors, but only a few. In the next section, we offer the discussion, conclusion and study implication for the limiting factors.

\section{DISCUSSION, CONCLUSION AND STUDY IMPLICATION}

Most carpenters in rural areas are informal (about 88 percent) with the capital of less than five million (about 77 percent), and they are a family managed (about 89 percent). These descriptive features of carpentry firms in rural Tanzania are more similar to the description of SMEs in Tanzania as found in (Kyaruzi and Ngowi, 2011; Tundui \& Tundui, 2012; Isaga et al., 2015; Msamula et al., 2016). This behaviour limit firms' ability to access potential business financing sources and hence the inability to invest in the machine. This indicates that rural carpenters should be formalized and transformed into small businesses. Also, they should change their ownership and management structures to be able to access other sources of business financing and support.

For carpenters to commercialize their product in the wood furniture industry they should be able to create value for customers and capture part of that value from customers. To create value, carpenters should be able to manufacture quality furniture, improve productivity, improve service delivery, and use quality inputs in manufacturing. So, any chain in the production process which limits the ability of carpenters to create value will also limit their abilities to commercialize their activities. This study uses the TOC to analyze the factors for the commercialization inability of carpenters in the wood furniture industry. The TOC suggests that the firm is constrained by its internal weakest link when the demand for the product is higher than the ability of the firm to meet such demand, that is, to supply enough products for the market. However, in the wood furniture industry, the causes of commercialization inability by carpenters are interdependent and related to the characteristics of firms. Therefore, for carpenters to commercialize their activities they should consider the link between factors for value creation inability characteristics of the firms. Some of the factors are described in the next section.

The use of old-style, mostly non-mechanical or not mechanized technologies such technologies limits the ability of carpenters to produce quality products in terms of design, shapes, and finishing. Also, carpenters use much time and energy/effort to manufacture a single product or part of the product which results in low productivity. Their inability to manufacture quality products and being less productive results in low sales volume and low profits. In this regard, carpenters remain relatively poor and cannot compete in the market with either imported furniture or with urban carpenters with technologies. Furthermore, the inability to create value for customers as well as capturing value from customers restrict the ability of these rural carpenters to invest in more productive technologies as well as to access quality inputs. This increases the gap between these firms and their competitors which makes them remains unchanged. This finding tallies with that of (Msamula et al., 2016). However, by using the TOC, this could be a symptom rather than the weakest link because different technologies are available for rural carpenters. The question could be, why carpenters are reluctant or not able to invest in technologies? For example, some carpentry groups 
were given basic machines for different activities, but they demonstrated no significant change in their product quality and customer service. This suggests that there is another weakest link that limits the ability of carpenters to commercialize their activities.

The financial limitation is the next important constraint that pointed out to limit the value creation abilities of carpenters in rural areas. Msamula et al., (2016) observed that most rural carpenters are constrained with financial resources to invest in their activities e.g. to buy quality raw materials and acquire more productive technologies. This limits their ability to create value in terms of both making quality furniture and improve productivity. Similarly, financial resources limit the ability of carpenters to acquire needed skills and competencies as they cannot afford to pay for the training. This limits their innovative abilities especially in designing, making, and finishing their products; improving service quality; and managing channels. The vicious cycle implies that the size of the firm remains unchanged (no firm growth) and the value creation inability also remains unchanged. However, firms were able to invest in other economic activities like agriculture and social activities. Even carpenters who have access to financial resources are still reluctant to invest in the activity. This suggests that financial resources are just a symptom and not a limiting factor for the commercialization abilities of carpentry activities in rural Tanzania.

Accordingly, most rural carpenters do the furniture making activity part-time and seasonal: They are mostly engaged in other economic activities like agriculture hence considers carpentry as a secondary activity. This attitude limits the ability of carpenters to invest in carpentry activities as they commit their limited funds to other primary economic activities. The inability to commit funds to the activity limit their access to technologies which affects the productivity and quality of furniture products. Because the furniture is not of good quality then they cannot access potential markets and hence affects value capture abilities. As a result, the small size of rural carpentry firms remains the same over time. This vicious cycle is as presented in figure 1 below:

FIGURE 1

THE BUSINESS ATTITUDE AND COMMITMENT VICIOUS CYCLE

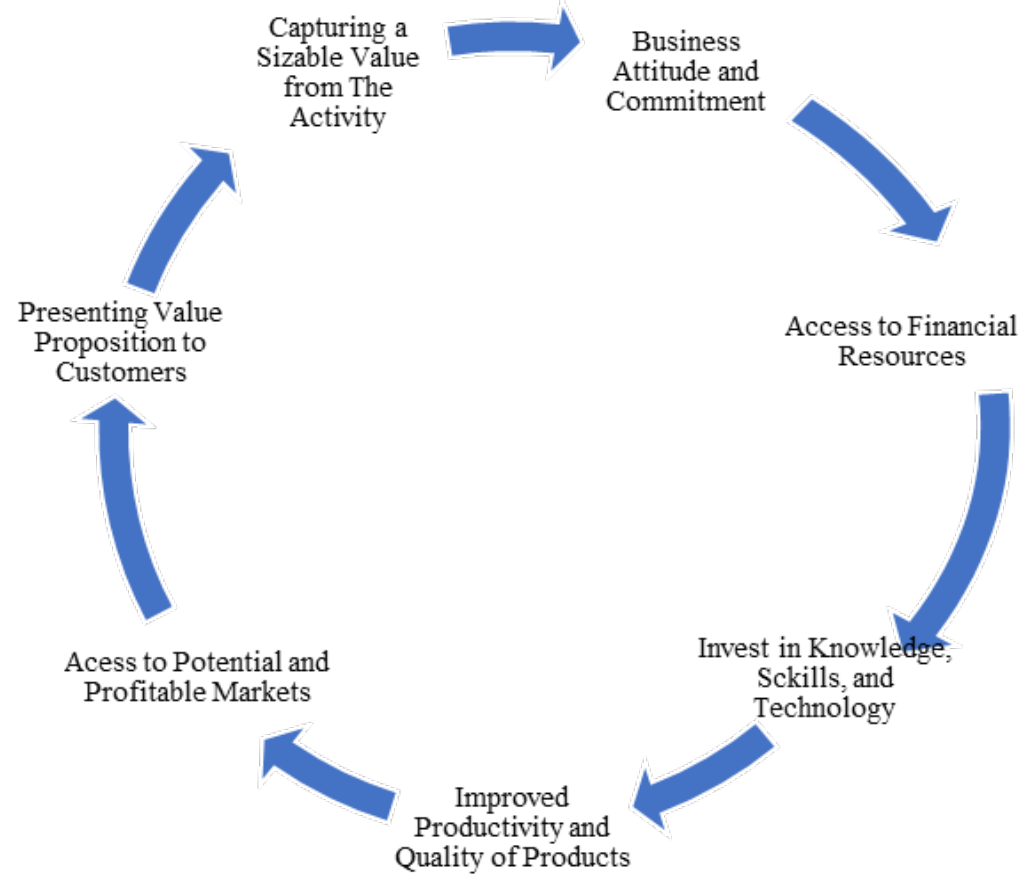

Source: Researcher, 2021 
Conclusively, the commercialization inabilities of the rural value chain in emerging markets, carpentry activities in Tanzania is due to the business attitude and commitment. Rural business people have a pessimistic attitude towards carpentry and the forest resources value chain. Most carpenters don't consider carpentry as an activity that can be commercialized to improve their economic and social condition but a second and part-time activity. Also, they think that the government and business supporting organizations should support them to commercialize their activities. And even when they are supported, they do not have or show total commitment towards the commercialization of the activity. It is therefore important to change this attitude so that they can be able to invest, acquire skills and knowledge necessary for the professionalization and hence commercialization of carpentry activities.

This study implies that the TOC, the cause-and-effect of the thinking tree analysis is a useful tool for analyzing reasons for the commercialization inability of carpenters in the furniture industry in rural areas. However, other theories like the Resources Based Theory and dynamic capabilities can be used to analyze such conditions of resources like valuable, rare, inimitable and non-substitutable. Similarly, the findings and conclusion of this study signify that carpenters performance in value creation is reliant on strategies to acquire some basic amenities like electricity, machine and skilled manufacturers while capitalizing on existing resources such as raw materials (timber) and social capital. So, the commercialization of carpentry activity is facilitated by the improvement of such amenities. Another implication is that focusing on one level or one factor will not improve the commercialization abilities of rural carpenters in the furniture industry in developing areas. Business supporting and development actors which support rural development in the wood furniture industry should work at different levels while focusing on different factors to attain desired results. That also implies the need for collaboration across such organizations that are meant to empower rural carpentry firms to be able to create customer value. To policymakers, especially those engaged in the rural value chain development policy, national forestry policy, and rural development policy, this study provides important information and finding on which they can rely upon decision making and policy formulations.

\section{REFERENCES}

Chikweche, T. (2013). Marketing at the bottom of the pyramid: market attractiveness and strategic requirements. Journal of Marketing Intelligence and Planning, 31(7), 764-787.

Collins, R.C., Dent, B., \& Bonney, L.B. (2015). A guide to value-chain analysis and development for Overseas Development Assistance projects. Australian Centre for International Agricultural Research: Canberra ACT 2601, Australia.

Dettmer, H.W. (2000). Constraints Management. A paper published from a chapter in the updated 2000 edition of The Certified Quality Management Guide, Quality America, USA.

Elliott, R., \& Timulak, L. (2005). Descriptive and interpretive approaches to qualitative research. $A$ Handbook of Research Methods for Clinical and Health Psychology, pp. 147-159.

Goldratt, E.M., \& Cox, J. (2004). The Goal - A Process of Ongoing Improvement (Third revised edition). North River Press Publishing Corporation, Great Barrington, MA.

Hair, J.F., Jr., Money, A.H., Samouel, P., \& Page, M. (2007). Research methods for business. John Wiley \& Sons Ltd, United States

Isaga, N. (2015). Owner-managers' demographic characteristics and the growth of Tanzanian Small and medium enterprises. International Journal of Business and Management, 10, 168-181. doi: 10.5539/ijbm.v10n5p168

Isaga, N. (2018). Start-up motives and challenges facing female entrepreneurs in Tanzania. International Journal of Gender and Entrepreneurship. https://doi.org/10.1108/IJGE-02-2018-0010

Isaga, N., Masurel, E., \& Montfort, K. (2015). Owner-manager motives and the growth of SMEs in developing countries: Evidence from the furniture industry in Tanzania. Journal of Entrepreneurship in Emerging Economies, 7(3), 190-211. 
Jaligot, R., David, C.W., Christopher, R.C., Berti, S., \& Joachim, S. (2016). Applying value chain analysis to informal sector recycling: A case study of the Zabaleen. Resources, Conservation and Recycling, 114, 80-91.

Jun, S., Dongmyung, L., \& Park, J. (2013). Determining business models in the bottom-of-the-pyramid markets. Journal of Industrial Management and Data Systems, 113(7), 1064-1082.

Junior, J.A., Marcelo, K., Andre, L.K., \& Daniel, P.L. (2004, April 30-May 3). Critical Issues about the Theory of Constraints Thinking Process - A Theoretical and Practical Approach. Paper presented at the Second World Conference on POM and 15th Annual POM Conference. Cancun, Mexico.

Kaplinsky, R., \& Morris, M. (2001). A Handbook for Value Chain Research. IDRC, Canada. Retrieved February 12, 2018, from http://asiandrivers.open.ac.uk/documents/Value_chain_Handbook_RKMM_Nov_2001.pdf

Kyaruzi, S.I., \& Ngowi, H.P. (2011). Fostering Entrepreneurial Agriculture in Tanzania. Mkuki na Nyota Publishers Ltd, Dar es Salaam Tanzania.

Majumder, M. (2012). A Critical Approach in Understanding Bottom of the Pyramid Propositions. Journal of Management and Public Policy, 3(2), 18-25.

Moynihan, G.P. (2014). Application of the Theory of Constraints for Capacity Requirements Analysis: A Case Study. International Journal of Applied Science and Technology, 4(2), 1-9.

Msamula, J., Vanhaverbeke, W., \& Petro, H. (2016). Rural entrepreneurship in Tanzania: Why are micro and small enterprises not creating value in the furniture manufacturing industry? Transnational Corporations Review, 8(4), 250-264. DOI: 10.1080/19186444.2016.1265768

Msamula, J., Vanhaverbeke, W., \& Tutuba, N. (2018). Influence of institutions on value creation activities of micro and small enterprises in rural Tanzania. Afrika Focus, 31(1), 187-211.

Osterwalder, A., \& Pigneur, Y. (2010). Business Model Generation: A Handbook for Visionaries, Game Changers, and Challengers. John Wiley \& So. Hoboken, New Jersey, USA.

Peprah, A.A., Giachetti, C., Larsen, M.M., \& Rajwani, T.S. (2021). How Business Models Evolve in Weak Institutional Environments: The Case of Jumia, the Amazon.Com of Africa. Organization Science. https://doi.org/10.1287/orsc.2021.1444

Porter, M.E. (1985). Technology and competitive advantage. Journal of Business Strategy, 5(3), 60-78.

Rahma, S. (2002). The Theory of Constraints' Thinking Process Approach to Developing Growth Strategies in Supply Chain. Working Paper ITS-WP-02-09, Sydney, Australia.

Saldana, J. (2013). The coding manual for qualitative researchers. Sage Publications: London.

Sanchez, P., \& Ricart, J.E. (2010). Business model innovation and sources of value creation in lowincome markets. European Management Review, 7(3), 138-154.

Saunders, M., Lewis, P., \& Thornhill, A. (2009). Research Methods for Business Students (5th Ed.). Harlow: Pearson Education.

Simatupang, T.M., Alan, C.W., \& Ramaswami, S. (2004). Applying the Theory of Constraints to Supply Chain Collaboration. Supply Chain Management International Journal, 9(1), 1-29.

Teece, D.J. (2018). Business models and dynamic capabilities. Long Range Planning, 51, 40-49. http://dx.doi.org/10.1016/j.lrp.2017.06.007

Tidd, J., \& Bessant, J. (2018). Managing Innovation. Integrating Technological, Market and Organizational Change (6th edition). TJ International Ltd, Padstow, Cornwall, UK.

Tundui, C., \& Tundui, H. (2012). Survival, Growth Strategies and Performance of Women-Owned Micro and Small Businesses in Tanzania. International Journal of Business and Management, 7(8), 143-155.

Tutuba, B.N., \& Vanhaverbeke, W. (2018). Beekeeping in Tanzania: Why is beekeeping not commercially viable in Mvomero? Afrika Focus, 31(1), 213-239.

Tutuba, N., \& Msamula, J. (2020). Industry architecture: A model to create value and appropriate value in the value system of rural economies in Tanzania. Journal of Academic Research in Economics, $12(3), 509-531$. 
Tutuba, N.B., Msamula, J.S., \& Tundui, H.P. (2019a). Business Model Innovation for Sustainable Beekeeping in Tanzania: A Content Analysis Approach. American Journal of Management, 19(1), 74-88. ISSN: 2165-7998

Tutuba, N.B., Tundui, H.P., \& Msamula, J.S. (2019b). Business Ecosystems as the Approach to Create Value and Appropriate Value for Small Firms in Emerging Markets. Journal of Strategic Innovation and Sustainability, 14(5), 90-107. https://doi.org/10.33423/jsis.v14i5.2525

Walsh, P.R. (2011). Creating a "values" chain for sustainable development in developing nations: Where Maslow meets Porter. Environ Dev Sustain., 13, 789-805. DOI 10.1007/s10668-011-9291-y

Yin, R.K. (2014). Case study research: Design and methods (5th Ed.). Sage Publications. United States.

Yin, R.K. (2018). Case Study Research and Applications: Design and Methods (6th Ed.). SAGE Publications, Inc.

Zott, C., \& Amit, R. (2014). Business model innovation: Towards a process perspective. In C. Shalley, M. Hitt, \& J. Zhou (Eds.), Oxford Handbook of Creativity, Innovation, and Entrepreneurship: Multilevel Linkages. Oxford University Press, New York: NY. 